\title{
STUDI RANCANGAN KENDARAAN RESPON DNA UNTUK MENDUKUNG PELAYANAN PRIMA POLRI DI ACEH
}

\section{STUDY OF DNA RESPONSE VEHICLE DESIGN TO SUPPORT THE EXCELLENT POLICE SERVICE IN ACEH}

\author{
Fadli C. Megawanto ${ }^{a}$, Kuwat Darmanto ${ }^{a}$, Teguh Budi Prasojo ${ }^{b}$ \\ a Pusat Teknologi Industri Pertahanan dan Keamanan, Deputi Bidang TIRBR - BPPT, \\ Gedung Hankam No. 256 Kawasan PUSPIPTEK - Serpong, Tangerang Selatan - 15314. \\ ${ }^{\mathrm{b}}$ Laboratorium Teknologi Kepolisian, Pusat Penelitian dan Pengembangan POLRI, \\ Jalan Trunojoyo 3 - Kebayoran Baru, Jakarta Selatan - 12110. \\ e-mail : fadli.cahya@bppt.go.id, litbang.POLRI@gmail.com
}

\begin{abstract}
Abstrak
Tantangan pelaksanaan tugas kepolisian terkait erat dengan situasi kondisi dan perkembangan lingkungan medan tugas serta kesiapan sumber daya. Keterbatasan personil, sarana serta jarak jangkau antar kantor wilayah kepolisian, akan mengurangi pelayanan prima tugas kepolisian. Oleh karenanya dibutuhkan sarana bantu peralatan material khusus kepolisian (Almatsus POLRI) yang bersifat bergerak (mobile). Salah satu upaya untuk mendukung tugas kepolisian dalam penanganan, pencarian dan pengumpulan informasi identitas diri pada proses penyidikan, bantuan korban kejahatan kriminal, teroris, kecelakaan, bencana dan sebagainya, maka POLRI perlu dilengkapi peralatan pendukung dalam pelaksanaan tugas di lapangan. Salah satunya adalah tersedianya kendaraan khusus lapangan yang dilengkapi peralatan respon DNA. Peralatan respon DNA yang dibawa kendaraan ini akan digunakan untuk mengidentifikasi, menghimpun dan menginventarisir filefile khas karakter DNA tubuh korban. Selanjutnya melalui kegiatan litbangyasa Puslitbang POLRI dan BPPT dilakukan survei penelitian kebutuhan Kendaraan Respon DNA di wilayah POLDA Aceh dan dilakukan perancangan Kendaraan Respon DNA. Spesifikasi hasil rancang bangun Kendaraan Respon DNA yang diharapkan sesuai kebutuhan adalah kendaraan dengan sistem penggerak $4 \times 2$, bertransmisi 5 kecepatan serta mudah dilakukan mobilisasi menggunakan transportasi udara maupun laut dengan dimensi panjang 5,04 meter, lebar 1,8 meter dan tinggi 1,81 meter.
\end{abstract}

Kata kunci : Kepolisian, Kendaraan Respon DNA, DNA

\begin{abstract}
The challenge of implementing police tasks is closely related to the conditions and development of the field environment and the readiness of resources. Limitations of personnel, facilities and distance between the regional offices of the police, will reduce the prime service of police duties. Therefore, it is required a special tool of police equipment (Almatsus POLRI) which is mobile. One of the efforts to support police tasks in the handling, searching and collecting of identity information on the investigation process, crime victims, terrorist, accident, disaster etc., Indonesian Police (POLRI) needs to be equipped with supporting equipment in the implementation of tasks in the field. One of them is the availability of special field vehicles equipped with DNA response equipment. The DNA response equipment brought by this vehicle will be
\end{abstract}


used to identify, collect and inventory the typical DNA character files of the victim's body. Furthermore, through the joint activities of research and development program between the Centre for Research and Development of POLRI and BPPT conducted a survey of DNA response needs of vehicles in the area of Aceh region Police (POLDA Aceh) and carried out the design of DNA Response Vehicle. Specification of expected DNA Response Vehicle is a vehicle with $4 \times 2$ drive system, 5 speed transmission and easy to mobilize by air or sea transportation with dimensions of $5.04 \mathrm{~m}$ length, $1.8 \mathrm{~m}$ wide and 1.81 height.

Key Words : Police, DNA response vehicle, Deoxyribo nucleic acid (DNA)

Diterima (received ) : 20 Mei 2018

Disetujui (accepted) : 23 Juli 2018
Direvisi (revised ) : 11 Juli 2018

sesuai dengan tuntutan tugas kepolisian. Sebagai gambaran saat terjadi peristiwa bencana tsunami, banjir, letusan gunung berapi, kecelakaan pesawat terbang dan kapal di laut, peristiwa bencana kebakaran, peristiwa teror pengeboman dan sebagainya yang memakan banyak korban jiwa dan sukar dikenali identitasnya serta lokasi kejadian yang jauh dari fasilitas rumah sakit. Hal ini memerlukan almatsus sarana respon DNA yang bersifat mobile untuk mendukung penyelidikan identitas korban di lapangan dengan cepat.

Terkait dengan tugas tersebut Puslitbang POLRI bersinergi dengan BPPT melakukan studi rancang bangun prototipe KR-DNA yang bersifat mobile/ bergerak guna mendukung pelayanan prima kegiatan polisi.

Hasil kegiatan studi rancang bangun KRDNA, diharapkan dapat digunakan sebagai model produk kendaraan operasional lapangan yang secara efektif digunakan di kesatuan wilayah kepolisian di Indonesia terutama pada kesatuan wilayah yang belum memiliki fasilitas peralatan DNA.

\section{BAHAN DAN METODE}

\section{Bahan Penelitian}

Sebagai bahan dasar kegiatan studi rancang bangun Kendaraan Respon DNA (KR-DNA) adalah melakukan sampling data kebutuhan almatsus KR-DNA di wilayah kerja Kepolisian Daerah (POLDA) Aceh. POLDA Aceh membawahi 23 kantor tingkat Kepolisian Resor (POLRES) yang tersebar dari wilayah tengah, utara, barat, timur, selatan hingga ke wilayah pengembangan daerah baru serta di ibu kota provinsi Banda Aceh dan beberapa pulau ${ }^{4)}$. Sebaran Kantor POLRES di wilayah Aceh ditampilkan pada Tabel 1. 
Tabel 1.

POLRES di wailayah POLDA ACEH

\begin{tabular}{|c|c|c|}
\hline No. & $\begin{array}{l}\text { Wilayah } \\
\text { Aceh }\end{array}$ & Kantor POLRES \\
\hline 1. & & $\begin{array}{l}\text { POLRES Banda Aceh - Banda } \\
\text { Aceh }\end{array}$ \\
\hline 2. & & POLRES Aceh Besar - Janto \\
\hline 3. & Aceh & POLRES Pidie Jaya - Pidie \\
\hline 4. & & POLRES Pidie - Sigli \\
\hline 5. & & POLRES Sabang - Sabang \\
\hline $6 .$. & & POLRES Aceh Utara - Lhoksukon \\
\hline 7. & & POLRES Aceh Tengah - Takengon \\
\hline 8. & $\begin{array}{l}\text { Aceh } \\
\text { Tengah }\end{array}$ & $\begin{array}{l}\text { POLRES Bener Meriah - Bener } \\
\text { Meriah }\end{array}$ \\
\hline 9. & & POLRES Gayo Lues - Gayo Lues \\
\hline 10. & & POLRES Aceh Barat - Meulaboh \\
\hline 11. & Aceh & POLRES Aceh Barat Daya \\
\hline 12. & & POLRES Aceh Nangan Jaya \\
\hline 13. & & POLRES Aceh Timur - Langsa \\
\hline 14. & & POLRES Langsa - Langsa \\
\hline 16. & Aceh & $\begin{array}{l}\text { POLRES Aceh Tamiang - Aceh } \\
\text { Tamiang }\end{array}$ \\
\hline 17. & & $\begin{array}{l}\text { POLRES Lokseumawe - } \\
\text { Lokseumawe }\end{array}$ \\
\hline 18. & & POLRES Bireun - Bireun \\
\hline 19. & & POLRES Simeulue - Sinabung \\
\hline 20. & & $\begin{array}{l}\text { POLRES Aceh Selatan -Tapak } \\
\text { Tuan }\end{array}$ \\
\hline 21. & Aceh & POLRES Aceh Tenggara - Kuacane \\
\hline 22. & Selatan & $\begin{array}{l}\text { POLRES Aceh Singkil - Tapak } \\
\text { Tuan }\end{array}$ \\
\hline 23. & & $\begin{array}{l}\text { POLRES Subulussalam - } \\
\text { Subulussalam }\end{array}$ \\
\hline
\end{tabular}

\section{Metodologi Penelitian}

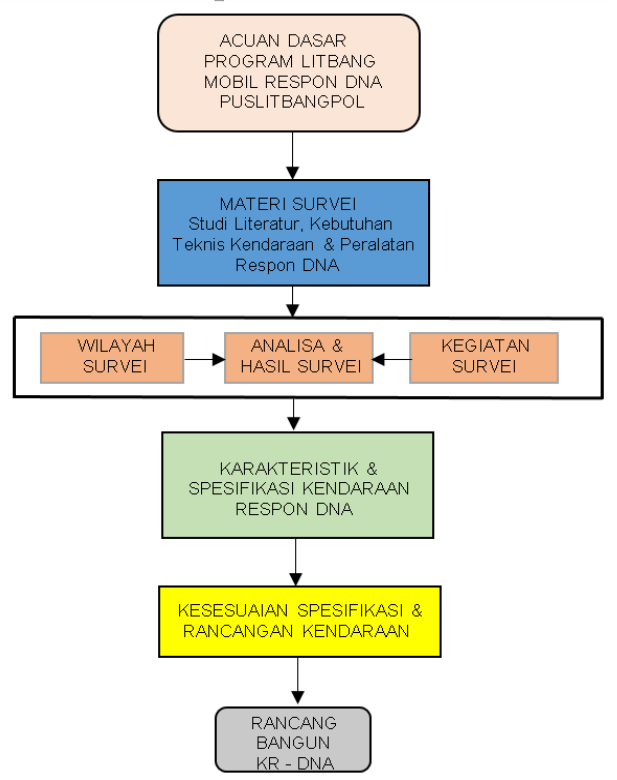

Gambar 1.

Metodologi Litbang KR-DNA
Metodologi penelitian perancangan mobil respon DNA kepolisian digambarkan sebagaimana ditampilkan pada diagram Gambar 1, serta uraian kegiatan utama penelitian disampaikan sebagai berikut.

\section{a. Studi Literatur}

- Dilakukan penghimpunan data dan informasi tentang KR-DNA.

- Dilakukan indentifikasi parameter terkait dengan rancang bangun KRDNA.

\section{b. Survei}

- Melakukan survei wawancara serta pengisian angket untuk mengetahui : kebutuhan operasi, jumlah kendaraan dan sarana dukung dari kesatuan wilayah kepolisian.

- Penyusunan karakteristik teknis KRDNA hasil; analisa data hasil survei sebagai acuan standar perancangan prototipe KR-DNA.

- Responden survei adalah; bagian Reskrimum, Biddokkes dan Sarpras di POLDA serta bagian Sat-Reskrim dan Bag.Sumda di POLRES khususnya yang menangani bidang penyidikan DNA dan sarana prasarana POLRI.

\section{c. Analisa dan Evaluasi}

- Melakukan penyusunan spesifikasi teknis Kendaraan Respon DNA dengan mempertimbangkan analisa wilayah operasi dan pola pengoperasian KR-DNA.

- Melakukan perancangan teknis prototipe Kendaraan Respon DNA.

- Melakukan pembangunan dan pengujian operasional/ pengujian fungsi prototipe Kendaraan Respon DNA.

\section{d. Mitra Kerja}

1. PUSLITBANG POLRI, sebagai narasumber untuk operation requirement kendaraan yang akan dihasilkan.

2. PUSDOKKES POLRI, sebagai Userl pengguna dan sebagai narasumber dari sisi teknis penanganan DNA/ technical asisstance 
M.I.P.I. Vol.12, No 2, Agustus 2018 - (97-104)

3. SARPRAS POLRI,
narasumber dari sisi
penanganan kendaraan.

\section{HASIL SURVEI}

\section{Wilayah Survei}

Untuk mengetahui tingkat kebutuhan sarana Kendaraan Respon DNA maka dilakukan survei lapangan di wilayah Kepolisian Aceh di tingkat wilayah POLDA dan POLRES. Survei tersebut dimaksudkan untuk mengetahui hal-hal terkait dengan kondisi medan operasi, kegiatan operasi, kebutuhan/ jumlah sarana dan peralatan pendukung yang tersedia. Pada Tabel 2 disampaikan sampel wilayah dan responden yang ada.

Tabel 2

Sampel Wilayah dan Responden

\begin{tabular}{clc}
\hline No. & \multicolumn{1}{c}{ Sampel Wilayah } & $\begin{array}{c}\text { Jumlah } \\
\text { Responden }\end{array}$ \\
\hline 1. & Ro. Sarpras POLDA NAD & 3 \\
2. & Dit. Reskrimum POLDA NAD & 4 \\
3. & Bid. Dokkes POLDA NAD & 4 \\
4. & Bag. Urkes POLRES & 2 \\
5. & Sat.Reskrim POLRES & 3 \\
\hline
\end{tabular}

\section{Materi Survei}

Materi survei utama disusun berdasarkan hal teknis kebutuhan kendaraan serta dilengkapi dengan kebutuhan peralatan respon DNA. Pokok-pokok materi survei utama ditampilkan pada Tabel 3.

Tabel 3.

Materi Survei Kendaraan

\begin{tabular}{|c|c|c|}
\hline No. & Materi Survei & Lingkup Kajian \\
\hline 1. & Jenis Kendaraan & Operasional lapangan \\
\hline 2. & $\begin{array}{l}\text { Kemampuan } \\
\text { kendaraan }\end{array}$ & $\begin{array}{l}\text { Jarak jelajah, Daya } \\
\text { jelajah, daya angkut }\end{array}$ \\
\hline 3. & $\begin{array}{l}\text { Spesifikasi } \\
\text { kendaraan }\end{array}$ & $\begin{array}{l}\text { Tenaga mesin, roda } \\
\text { penggerak, ruang } \\
\text { muat }\end{array}$ \\
\hline 4. & $\begin{array}{l}\text { Peralatan } \\
\text { pendukung }\end{array}$ & $\begin{array}{l}\text { Alat komunikasi, Alat } \\
\text { bantu darurat, Alat } \\
\text { medis DNA }\end{array}$ \\
\hline 5. & Sarpras di daerah & $\begin{array}{l}\text { Ketersediaan } \\
\text { bengkel, Suku } \\
\text { cadang }\end{array}$ \\
\hline 6. & Personil & Keahlian, Penugasan \\
\hline
\end{tabular}

\section{Analisa Wilayah Operasi}

Melihat jauhnya jarak bentang antar POLRES serta variasi kondisi geografis tanah pegunungan dan pantai di provinsi Aceh menjadikan aspek keterbatasan infrastruktur penghubung menjadi salah satu faktor yang dipertimbangkan 5). Sebagai gambaran jarak yang terlihat untuk melakukan koordinasi antar POLDA dan POLRES, terlihat relatif berdekatan seperti antara POLDA Banda Aceh dan POLRES Pidie. Berjarak tempuh sekitar $113 \mathrm{Km}$ dengan menggunakan jalur pantai dapat ditempuh selama 3 jam. Demikian juga tampak pada jarak jangkau antar POLDA di Banda Aceh dan POLRES Gayo Lues di daerah pegunungan di daerah Aceh Tengah yang harus melalui POLRES Bireun, dengan jarak total sekitar $450 \mathrm{Km}$. Pertama dengan menggunakan jalur jalan menyusur pantai ke Bireun akan menempuh jarak sekitar $220 \mathrm{Km}$ dan dilanjutkan menggunakan jalur jalan pengunungan mencapai $240 \mathrm{Km}$. Hal ini dengan mobil akan ditempuh waktu sekitar 56 jam perjalanan. Demikian juga untuk kordinasi POLDA dan POLRES terjauh seperti Banda Aceh dan Singkil, dengan jalur kendaraan yang ada dapat ditempuh sampai 12 jam perjalanan lewat jalur barat. Hal jarak kordinasi ini seperti ditampilkan pada peta wilayah kordinasi pada Gambar 2.

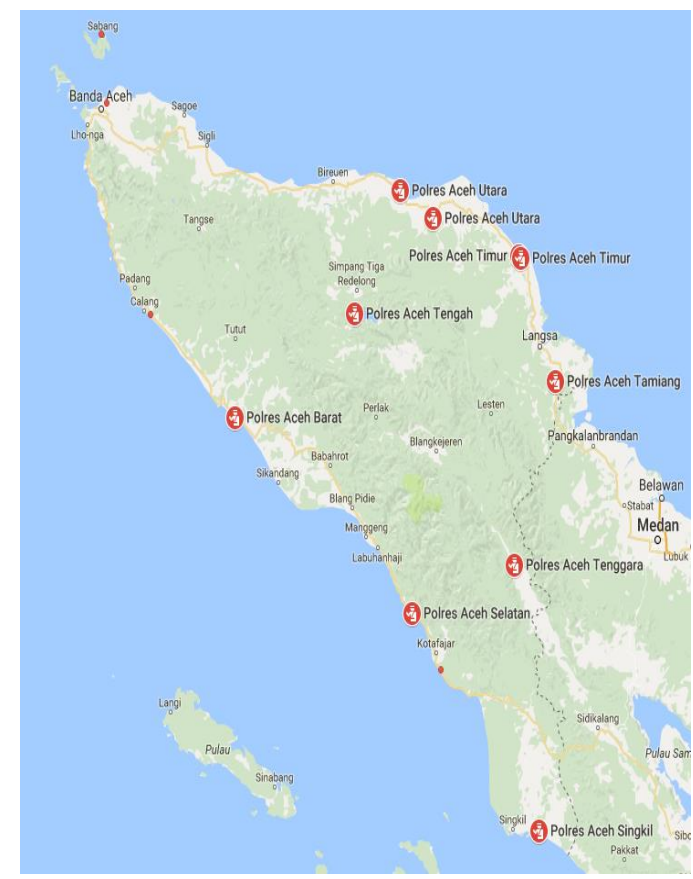

Gambar 2.

Peta Wilayah POLDA ACEH 


\section{Analisa Pola Pengoperasian}

Rancangan pola pengoperasian Kendaraan Respon DNA POLRI diselaraskan dengan kebutuhan operasional antar POLDA dan POLRES serta antar POLRES dan POLRES dengan jarak terdekat sesuai situasi-kondisi yang ada. Untuk itu dalam upaya melaksanakan pelayanan prima POLRI di seluruh wilayah POLDA Aceh, maka selayaknya pola operasi setiap kendaraan tersebut harus dapat menangani setiap 2 POLRES terdekat serta bantuan layanan cadangan dari POLRES yang lain ${ }^{6}$ ). Oleh karenanya minimal 5 unit kendaraan harus tersedia, yang ditempatkan tersebar di POLDA Banda Aceh, POLRES Langsa, POLRES Aceh Barat, POLRES Singkil dan POLRES Simeulue (khusus di luar pulau Sumatera). Pola Operasi Kendaraan Respon DNA untuk dapat melayani seluruh wilayah POLDA Aceh di tampilkan pada Gambar 3. Dalam kondisi darurat pola operasi Kendaraan Respon DNA dapat dibantu juga oleh kendaraan medis lain yang tersedia di POLRES terdekat ${ }^{7)}$.

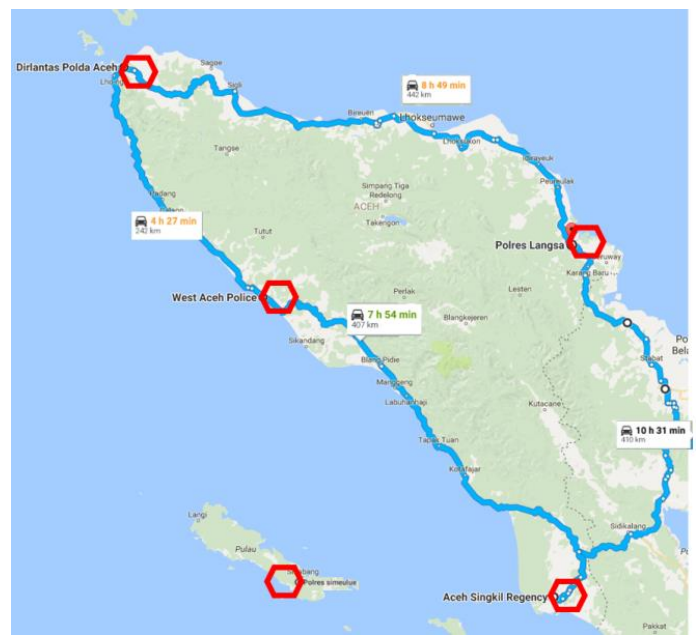

Gambar 3.

Pola operasi KR-DNA antar

POLDA dan POLRES di Aceh

\section{Karakteristik Kendaraan}

Dari materi dan hasil survei yang dilaksanakan diperoleh gambaran data karakteristik Kendaraan Respon DNA yang diharapkan :

a. Jenis kendaraan. Rata rata responden menghendaki jenis kendaraan lapangan jenis Sport Utility Vehicle (SUV-Double cabin) dengan 5 pintu. Diawaki 3-4 petugas medis. Terdiri dari 1 orang komandan Perwira pertama bidang medis, 1-2 orang tenaga pembantu medis dan 1 pengendara.

b. Spesifikasi kendaraan. Kendaraan cukup kuat dioperasikan di medan tanjakan. Dilengkapi mesin diesel kapasitas 2500-3000 cc dan roda penggerak $4 \times 4$. Mengingat medannya sampai jauh di pedalaman, maka kapasitas tanki bahan bakar harus cukup mampu untuk operasional hingga 6 jam.

c. Peralatan pendukung. Peralatan di kendaraan untuk tugas kepolisian di lapangan minimal harus dilengkapi antara lain lampu rotari sirine dan public adressor, alat komunikasi lapangan (RIG dan HT), generator set portable, electric winch.

d. Kompartemen kendaraan. Pada kompartemen bagian belakang kendaraan untuk penempatan peralatan respon DNA.

Hasil tabulasi data survei dan wawancara di lapangan di tampilkan pada Tabel Lampiran 1 .

\section{PEMBAHASAN}

\section{Spesifikasi Teknik Rancangan} Dasar Kendaraan Respon DNA

a. Dari hasil survei yang dilakukan analisa data lapangan serta ditetapkan rancangan dasar (basic design) Kendaraan Respon DNA yang diinginkan. Basis kendaraan lapangan yang akan digunakan adalah kendaraan jenis Sport Utility Vehicle (SUV) yang sudah diproduksi di dalam negeri. Dikarenakan, bila menggunakan kendaraan jenis lain, misal kendaraan jenis Multi Purpose Vehicle (MPV), ini sangat tidak cocok digunakan pada medan off road, mengingat daerah pedalaman di Indonesia juga banyak yang perlu melintasi medan off road untuk mencapainya. Selain itu, faktor ketersediaan komponen, sarana dan prasarana bengkel yang ada 
M.I.P.I. Vol.12, No 2, Agustus 2018 - (97-104)

hingga ke kota pelosok kabupaten.

b. Kendaraan Respon DNA dilengkapi mesin diesel 2500 3000 cc dan penggerak roda $4 \times 4$ dan memiliki torsi maksimum hingga $3500 \mathrm{kgm} / \mathrm{rpm}{ }^{8)}$. Bahan bakar diesel dipertimbangkan karena mudah didapatkan di lapangan. Gambar 4 dan Gambar 5 menampilkan bentuk rancangan dasar Kendaraan Respon DNA.

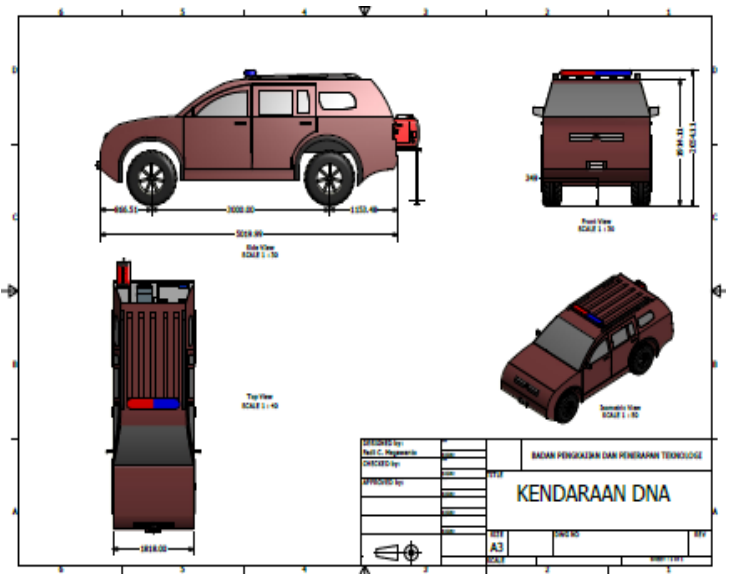

Gambar 4.

Rancangan dasar KR-DNA

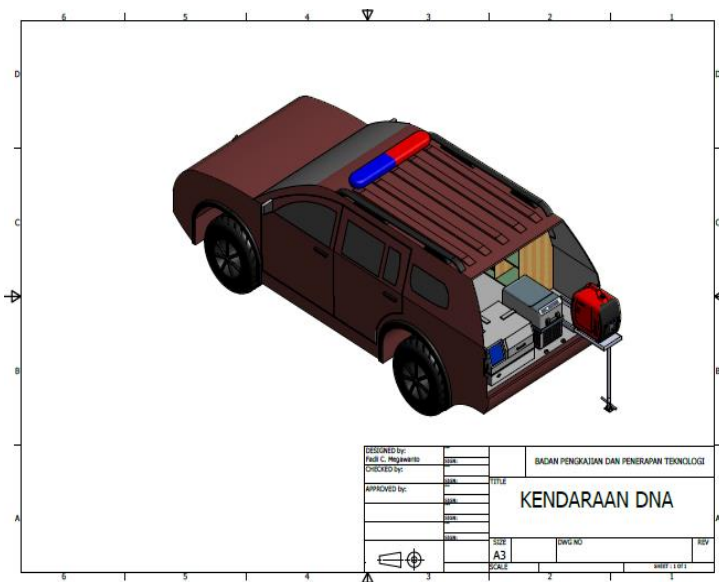

Gambar 5

Rancangan dasar KR-DNA 3D

c. Rancangan Kendaraan Respon DNA dilengkapi kabin dibelakang untuk penempatan peralatan utama pengambilan sampel DNA. Pada Gambar 6 ditampilkan susunan layout penempatan seluruh peralatan di dalam kabin kendaraan.
Tabel 4.

Peralatan pendukung respon DNA

\begin{tabular}{|c|c|c|}
\hline No. & Peralatan & Fungsi \\
\hline 1. & $\begin{array}{l}\text { Rapid DNA } \\
\text { Analysis }\end{array}$ & $\begin{array}{l}\text { Penguji sampel DNA } \\
\text { (simultan } 5 \text { sampel), } \\
\text { waktu uji } \pm 85 \text { menit. } \\
\text { Bobot peralatan } \pm 50 \\
\text { kg }\end{array}$ \\
\hline 2. & Small Refrigerator & $\begin{array}{l}\text { Tempat penyimpanan } \\
\text { sampel-sampel } \\
\text { berupa jaringan dan } \\
\text { darah. Dilengkapi } \\
\text { sistem pendingin } \\
\text { untuk memelihara } \\
\text { keawetan sampel. } \\
\text { Bobot peralatan } \pm 20 \\
\text { kg. }\end{array}$ \\
\hline 3. & Genset $2 \mathrm{KVa}$ & $\begin{array}{l}\text { Digunakan sebagai } \\
\text { sumber tenaga listrik } \\
\text { untuk pengoperasian } \\
\text { alat uji DNA saat } \\
\text { dilapangan. } \\
\text { Bobot peralatan } \pm 24 \\
\text { kg. }\end{array}$ \\
\hline 4. & $\begin{array}{l}\text { LED Portable } \\
\text { Rechargeable } \\
\text { Lighting System }\end{array}$ & $\begin{array}{l}\text { Sebagai lampu } \\
\text { penerangan malam } \\
\text { hari dilapangan saat } \\
\text { proses pengambilan } \\
\text { sampel. } \\
\text { Bobot peralatan } \pm 10 \\
\text { kg. }\end{array}$ \\
\hline 5. & $\begin{array}{l}\text { Field forensic } \\
\text { investigation light } \\
\text { source }\end{array}$ & $\begin{array}{lr}\text { Lampu pendektesi } \\
\text { noda pada } & \text { Tempat } \\
\text { Kejadian } & \text { Perkara } \\
\text { (TKP), } & \text { untuk } \\
\text { mengetahui apakah } \\
\text { ada material biologis } \\
\text { yang dapat digunakan } \\
\text { sebagai sumber DNA } \\
\text { untuk pemeriksaaan. }\end{array}$ \\
\hline 6. & $\begin{array}{l}\text { Rapid stain } \\
\text { identification }\end{array}$ & $\begin{array}{l}\text { Uji pendahuluan untuk } \\
\text { menentukan apakah } \\
\text { benar noda tersebut } \\
\text { adalah material } \\
\text { biologis atau bukan. } \\
\text { Terdiri dari } 3 \text { kit untuk } \\
\text { menguji darah, mani } \\
\text { dan air liur (saliva) } \\
\text { korban. }\end{array}$ \\
\hline 7. & $\begin{array}{l}\text { Alat bedah } \\
\text { pengambil sampel } \\
\text { (minor surgery kit) }\end{array}$ & $\begin{array}{l}\text { Peralatan bedah } \\
\text { seperti pisau scalpel, } \\
\text { pinset dll, digunakan } \\
\text { untuk pengambilan } \\
\text { sampel dari tubuh } \\
\text { manusia. }\end{array}$ \\
\hline 8. & $\begin{array}{l}\text { Radio komunikasi } \\
\text { mobil/RIG \& Radio } \\
\text { komunikasi } \\
\text { tangan/ HT }\end{array}$ & $\begin{array}{lr}\text { Digunakan } & \text { untuk } \\
\text { melakukan } & \\
\text { komunikasi } & \text { didalam } \\
\text { pelaksanaan } & \\
\text { mobilisasi } & \text { maupun } \\
\text { pengambilan } & \text { sampel } \\
\text { DNA. } & \end{array}$ \\
\hline
\end{tabular}

Sumber : Puslabfor POLRI ${ }^{\text {9) }}$ 
d. Beberapa jenis peralatan utama yang akan ditempatkan pada Kendaraan Respon DNA guna mendukung kegiatan pengambilan sampel DNA di lapangan, sebagaimana ditampilkan pada Tabel 4 .

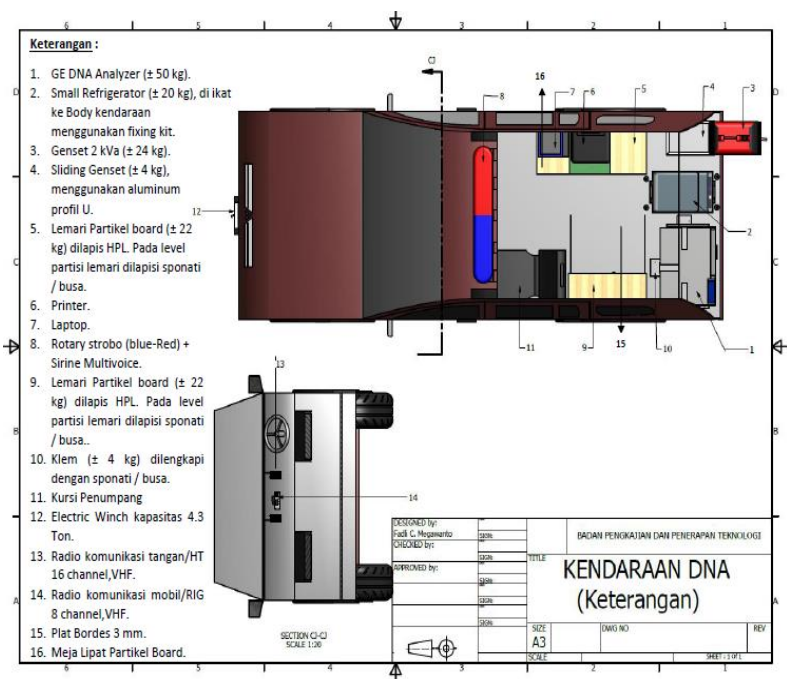

Gambar 6.

Tampak Atas-penempatan komponen pada kendaraan DNA

\section{Spesifikasi Teknis Unjuk Kerja Utama Kendaraan Respon DNA}

Sebagai kendaraan lapangan dengan tenaga mesin diesel 2000-3000 cc, KR-DNA dipilih jenis kendaraan SUV dengan konsumsi bahan bakar berkisar antara 8-10 $\mathrm{km} / \mathrm{liter}$, pada kondisi transmisi $4 \mathrm{WD}$. Dengan dijalankan dalam konsumsi bahan bakar berkisar antara $8 \mathrm{~km} / \mathrm{liter}$, maka minimum kelengkapan tangki bahan bakar volume penuh 60 liter kendaraan mampu menempuh jarak kurang lebih $480 \mathrm{~km}$ pada kondisi jalan normal dan transmisi 4WD tidak digunakan secara penuh ${ }^{8)}$. Untuk meredam getaran pada kendaraan jenis ini, maka peralatan diberikan damper berupa sponati. Sedangkan petugas yang berada di kursi belakang, tetap nyaman dikarenakan tidak merubah total posisi tempat duduk baris tengah. Dengan mengkaitkan kondisi wilayah operasi dan pola pengoperasian KR-DNA untuk pelayanan antar POLRES maka jarak tempuh terjauh sekitar $450 \mathrm{Km}$ masih dapat dilayani tanpa kesulitan kekurangan bahan bakar di lapangan.

\section{SIMPULAN}

1. Biddokkes POLDA Aceh selaku pelaksana tugas di dalam melakukan pengambilan sampel DNA sebagai informasi data identitas korban tindak pidana kriminal, kecelakaan, bencana alam maupun kejadian darurat memerlukan almatsus Kendaraan Respon DNA untuk segera mendapatkan hasil dengan cepat dan akurat.

2. Rancangan Kendaraan Respon DNA sebagai kendaraan operasional lapangan digunakan jenis SUV-double cabin, menggunakan mesin diesel bertenaga 2500-3000 cc, dengan kapasitas tangki 70 liter, berpenggerak $4 \times 4$, produk dalam negeri dengan dukungan fasilitas komponen kendaraan dan bengkel perawatan di daerah pelosok.

3. Rancangan Kendaraan Respon DNA harus dilengkapi peralatan pendukung antara lain:

a) Peralatan pengambilan sampel dan analisa DNA.

b) Peralatan Alkom.

c) Peralatan Penerangan/ genset.

d) Peralatan pendukung tugas kepolisian

\section{REKOMENDASI}

1. Diperlukan kendaraan lapangan khusus, dilengkapi dengan peralatan pengambilan sampel dan analisa DNA guna mendukung penyidikan suatu kasus yang terkait dengan kebutuhan informasi data identitas korban.

2. POLDA Aceh dengan wilayah pantai dan gunung dengan jarak jangkau antar POLRES yang jauh perlu dilengkapi dengan minimal 5 unit Kendaraan Respon DNA.

3. Untuk efektifitas pola pengoperasian Kendaraan Respon DNA antar POLRES, perlu dilakukan pelatihan pengawakan untuk kendaraan dan peralatan pendukung serta dilengkapi manual book sebagai panduan dalam tata cara pengambilan data dan analisa DNA.

4. Pentingnya informasi data sampel dan analisa DNA, maka perlu disiapkan fasilitas pendukung penyimpanan data DNA secara permanen. 


\section{UCAPAN TERIMA KASIH}

Kajian perancangan Kendaraan Respon DNA Kepolisian ini merupakan salah satu hasil kerjasama lantara Puslitbang POLRI dan Pustekinhan BPPT dalam program kegiatan litbangyasa Pembuatan Prototipe Kendaraan Respon DNA dalam mendukung Pelayanan Prima POLRI TA 2015. Terkait dalam kegiatan ini disampaikan ucapan terima kasih kepada Brigjen Pol Mamandoa, Ka. Puslitbang POLRI dan Dr. Samudro, Ka. Pustekinhan BPPT yang sangat mendorong pelaksanaan kegiatan ini.

\section{DAFTAR PUSTAKA}

1. Tim ALMATSUS PTIPK BPPT, Paparan: Peran BPPT dalam rangka Pengembangan Teknologi untuk Mendukung dan Mendorong Terwujudnya Industri Kepolisian, Rakernis Puslitbang POLRI 2013, Cisarua, 23 Oktober 2013.

2. Puslitbang POLRI, Laporan Hasil Penelitian tentang Pembuatan Prototype Kendaraan Respon DNA dalam rangka Pelayanan Prima di Wilayah POLDA Aceh, Jakarta, 2015 (tidak dipublikasikan)

3. https://id.wikipedia.org/wiki/Asam_deoks iribonukleat. Februari, 2016
4. https://www.POLRI.go.id/tentangsatwil.p hp\#xxPOLDA20. Juli 2015

5. Musolino, G., Polimeni, A., Rindone, C., and Vitetta, A., Travel time forecasting and dynamics routes design for emergency vehicles, Procedia - Social and Behavioral Sciences No. 87, ELSEVIER, 2013.

6. Camacho-Collados, M., Liberatore, F., and Angulo, J.M., A multi-critera Police districting problem for the efficient design of patrol sector, European Journal of Operational Research No. 246 ELSEVIER, 2015

7. Liu, Y., Zongzhi, L., Liu, J., and Patel, $\mathrm{H}$., A double standard model for allocating limited emergency medical service resources ensuring service reliability, Journal Transportation Research Part C, No. 69 ELSEVIER, 2016.

8. http://www.tribunnews.com/regional/201 7/04/10/menyusuri-jejak-suku-mante-dipedalaman-hutan-aceh. April, 2017.

9. http://wartalabfor.blogspot.com/2010/05/ mengenal-lebih-dekat-puslabfor.html. Desember, 2015.

10. https://neton.id/auto/1131-1131/. Februari 